\title{
Methodology of udder description and the effect on somatic cell count in Czech White Shorthaired goat breed")
}

\author{
KLÁRA NOVOTNÁ, ALENA SVITÁKOVÁ*, JANA RYCHTÁŘOVÁ*, \\ MILENA FANTOVÁ, LENKA NOHEJLOVÁ
}

\begin{abstract}
Department of Animal Husbandry, Faculty of Agrobiology, Food and Natural Resources, Czech University of Life Sciences in Prague, Kamýcká 129, 165 21, Prague 6 - Suchdol, Czech Republic *Institute of Animal Science in Prague, Přátelství 815, 104 00, Prague 10 - Uhříněves, Czech Republic
\end{abstract}

\section{Novotná K., Svitáková A., Rychtářová J., Fantová M., Nohejlová L. Methodology of udder description and the effect on somatic cell count in Czech White Shorthaired goat breed}

\section{Summary}

This study evaluated the effect of the linearly described shape traits of goat udders on somatic cell count. In a herd of 487 white shorthaired goats, seven traits (udder symmetry, udder depth, udder width, teat length, teat placement, rear udder attachment and udder cleft) were assessed in relation to somatic cell count in milk. The average somatic cell count was $1.3 \mathrm{mill}$ cells $/ \mathrm{ml}$ when considering the environmental effects (month and year of performance testing, lactation number. The somatic cell count is influenced by the depth $(p=0.0015)$ and width $(p=\mathbf{0 . 0 2 6 8})$ of the udder. The results demonstrate that some traits of the udder shape influence the somatic cell count and can be considered as functional traits indicating animal health and herd profitability. After further studies, the methodology for linear description of the udder could be used for other dairy goat breeds, not only in the Czech Republic.

Keywords: goat milk, goat's udder, somatic cell count, teats

In recent years, dairy goat farming has expanded in the Czech Republic as a result of increasing demand for high-quality products from goat milk. Cow milk is dominant in the world milk production, but goat milk ranks third. Goat milk is used in the Czech Republic mainly for the manufacture of cheeses and other dairy products, so it is very important to focus on its quality and yield. It should be emphasized that the quantity and quality of milk depend on many factors. The main include animal health $(5-7,9,19)$. Milk is a highly valuable biological fluid composed of water, proteins, fats, sugars, minerals, etc. Other important components naturally occurring in raw milk are somatic cells. Somatic cell count is used as an indicator of udder health and milk quality $(2,17)$. Milk secretion in goats is apocrine, whereas in cows it is merocrine, which partly explains the higher count of somatic cells in goat milk without any relation to mastitis (12). Maintenance of the normal physiological function of the mammary

1) This work was supported by grant no. QJ1510137 from the NAZV Agency of the Ministry of Agriculture of the Czech Republic. gland is essential for the production of high-quality milk and healthy offspring (3). The morphology of the udder affects its milkability, capacity for machine milking, the production and composition of milk, the resistance of the mammary gland to diseases, and the ability of kids to find and grasp the teat $(1,11)$. For this reason, greater attention should be paid to the study of goat udder anatomy. This study summarizes a pilot research that has contributed to the formulation of a methodology for a linear description of the shape traits of goat udders. The relationship between the udder shape and the quality and microbial contamination of milk were also studied, which is economically important for breeders.

\section{Material and methods}

Herd summary data. The evaluation of goat udders was made on a farm where white shorthaired goats belonging to the gene resources of the Czech Republic are kept. Measurements were carried out before the morning milking when the animals were tied in a milking room. The method 


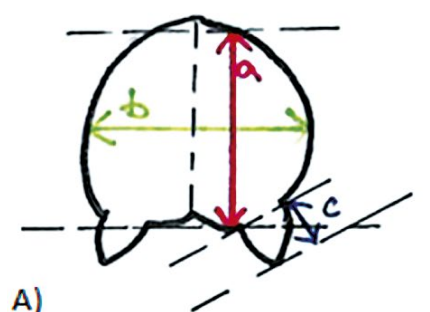

A)

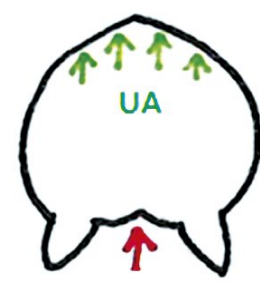

UC

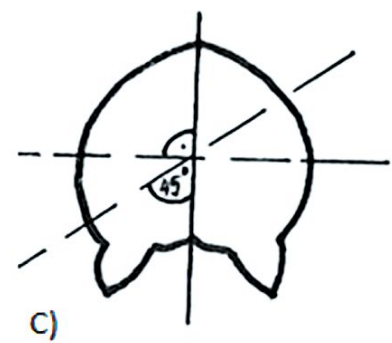

Fig. 1. Linear description of the udder shape

Explanations: A) a - udder depth, b - udder width, c - teat length; B) UA - rear udder attachment, UC - udder cleft; C) teat placement

for a linear description of dairy goat udders is based on a methodology for dairy sheep published by Milerski and Schmidova (11) and includes a total of 7 udder traits. Udder depth, udder width and teat length were measured exactly to the nearest $1 \mathrm{~cm}$ using a ruler with a measuring range of $30 \mathrm{~cm}$. Other traits, i.e. udder symmetry, teat placement, udder cleft and rear udder attachment, were assessed subjectively using a five-score scale. The linear description of the udder is presented in Figure 1. All measurements were done by 1 person.

Udder symmetry (US) was assessed subjectively as the first of the udder traits. Goats with asymmetrical udders were not included in the evaluation.

Udder depth (UD) was measured from the rear with a ruler to the nearest $1 \mathrm{~cm}$. UD was measured from the upper edge of the udder to the lowest point of the udder.

Udder width (UW) was measured from the rear with a ruler to the nearest $1 \mathrm{~cm}$. UW was measured at the widest part of the udder.

Teat length (TL) was measured from the rear with a ruler to the nearest $1 \mathrm{~cm}$. If the teats were visibly of different lengths, the longer teat was measured. TL was measured from the base to the tip of the teat.

Teat placement (TP) was assessed from the rear, using a five-score scale: 1 -almost perpendicular position of teats, teats placed on the bottom of the udder, 2 - teats pointing moderately sideways, placed on the lower edge of the udder, 3 - the teat angle is approximately $45^{\circ}$ from the intermammary groove, 4 - teats are placed on the udder sides, 5 teats point horizontally, placed high on the udder flanks.

Udder cleft (UC) was assessed as the depth of the intermammary groove, which is an indicator of the strength of the median suspensory ligament. It was assessed from the rear using a five-score scale: 1 - pronounced udder cleft, very pronounced suspensory ligament, 2 - less pronounced udder cleft, pronounced suspensory ligament, 3 - perceptible suspensory ligament, clear udder cleft, 4 - unclear udder cleft, 5 - loose suspensory ligament, part of the udder is below the teat level.

Rear udder attachment (UA) was assessed in terms of its width and how well the udder filled the room provided by the hind legs. The assessment was made from the rear using a five-score scale: 1 - very wide attachment, the room provided by the legs completely filled, 2 - wide attachment, the room provided by the legs nearly filled, 3 - intermediate attachment, room enough for the udder, 4 - weaker attachment, droopy udder, 5 - very weak attachment, baggy udder, skin folds.

Fig. 2. A properly formed symmetric udder of a goat, TP $-2, \mathrm{UC}-2, \mathrm{UA}-\mathbf{1}$

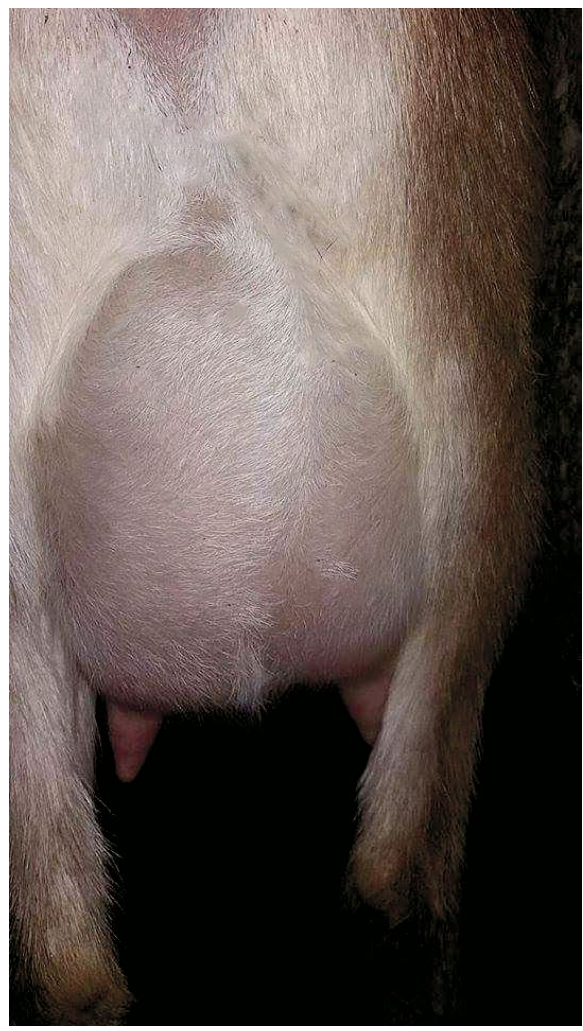

Database of performance testing. The linear description of udders was compared with the milk performance of goats and somatic cell count. All data for milk quality traits (somatic cell count) used in this study were obtained from the official database of the Czech-Moravian Breeders Corporation. The animals without performance records were excluded from further analysis. The database contained 2727 somatic cell count records for 343 goats. The data on milk performance were collected in 2016 and 2017. The goats were at different lactations (lactation 2-7). The highest number of somatic cell count data were obtained from goats at lactation 4 (27\% of data), $20 \%$ of data from lactation 3 , and about $12 \%$ of data from the remaining lactations.

Statistical analysis. Data were evaluated by a mixed model (PROC MIXED, SAS 9.2, 2004) with repeatability where the animal was a replication. The effects comprised the year of milk sampling, the month of milk sampling and the linear description trait. If the trait was assessed in classes (TP, UA, UC), the effect was considered within the class. In other cases (UD, US, TL), linear and quadratic regressions were computed for the given linear description trait.

\section{Results and discussion}

The average somatic cell count (Tab. 1) was 1.3 mill cells $/ \mathrm{ml}$, and the median was 605.5 thousand. The incidence of somatic cells was higher mainly at the beginning and at the end of lactation, which was taken into account in the effect of the sampling month in relation to kid delivery seasonality. The standard somatic cell count in goat milk in the United States is $1 \times 10^{6}$ cells/ml (13), but no such count has yet been laid down in the European Union (4). Data were collected from March to September, and the highest number of records came from June. UD and US showed lower 
Tab. 1. Average somatic cell count in relation to particular linear description traits of the goat's udder

\begin{tabular}{|l|l|c|c|c|c|c|c|c|c|}
\hline \multicolumn{1}{|c|}{ Variable } & \multicolumn{1}{|c|}{ Unit } & $\mathrm{n}$ & Mean & Std error & Std dev & Min & Max & Median & Coeff. of variation \\
\hline SC & $1 \times 10^{3}$ cells/mI & 2727 & 1297.98 & 34.62 & 1807.59 & 5 & 5999 & 605.5 & \\
UD & $\mathrm{cm}$ & 2727 & 15.83 & 0.06 & 3.11 & 8 & 27 & 15 & 19.67 \\
UW & $\mathrm{cm}$ & 2727 & 14.13 & 0.03 & 1.79 & 5 & 20 & 14 & 12.66 \\
TL & $\mathrm{cm}$ & 2727 & 5.14 & 0.04 & 1.93 & 2 & 11 & 5 & 37.56 \\
TP & point & 2727 & 1.72 & 0.01 & 0.64 & 1 & 5 & 2 & 37.18 \\
UA & point & 2727 & 3.26 & 0.02 & 1.22 & 1 & 5 & 3 & 37.31 \\
UC & point & 2727 & 2.85 & 0.02 & 1.19 & 1 & 5 & 3 & 41.84 \\
Month & & 2727 & 6.17 & 0.03 & 1.77 & 3 & 9 & 6 & \\
Lactation & & 2727 & 4.25 & 0.03 & 1.54 & 2 & 7 & 4 & \\
\hline
\end{tabular}

variability in the records than TL and the traits evaluated with a score scale. The TP median was 2 , which means that teats on the lower edge of the udder pointed moderately sideways (Fig. 2). Udder cleft 3 indicates that the majority of goats in the herd had a perceptible suspensory ligament and a clear udder cleft, while the intermediary udder attachment also prevailed when the room provided by the legs and the abdominal cavity for udder attachment was ample enough. Somatic cell count is influenced by many factors, such as the animal species, milk production, parity, lactation stage, individual and environmental factors, herd management, milking hygiene, health of the udder and its shape $(14,15)$. The analysis of particular effects shows that, when considering the environmental effects (month and year of performance testing, lactation number), the somatic cell count is influenced by udder depth $(p=0.0015)$ and width $(p=0.0268)$. Variability in the other traits is too high, and their influence cannot be significantly determined from the present sample. Only statistically significant relationships are shown in the graphs (Fig. 3 and 4). Fig. 3 represents the relationship between somatic cell count and udder depth. The graph indicates that the deeper the udder, the higher the somatic cell count. The effect of udder width on the somatic cell count is illustrated in Fig. 4. The curve shows a downward trend in SCC, and the udder of 13-17 $\mathrm{cm}$ in width seems optimum, but for wider udders the somatic cell count starts increasing again. It is still unclear whether somatic cells (SCs) have a positive or negative influence on milk quality and manufacture of dairy products. The somatic cell count is used as an indicator of udder health and milk quality because SCs participate in the mammary gland protection from infection as a component of the innate immune system (8). According to most authors (10, 14, 17), somatic cells contained in milk are considered as undesirable. Their large amount is related to a decrease in milk production and inflammations of the mammary gland causing bacterial problems in milk, which result in changes in milk composition and in characteristics of dairy products. Besides the immune function of the udder and protective functions in milk, it has been proven recently that SCs often positively influence

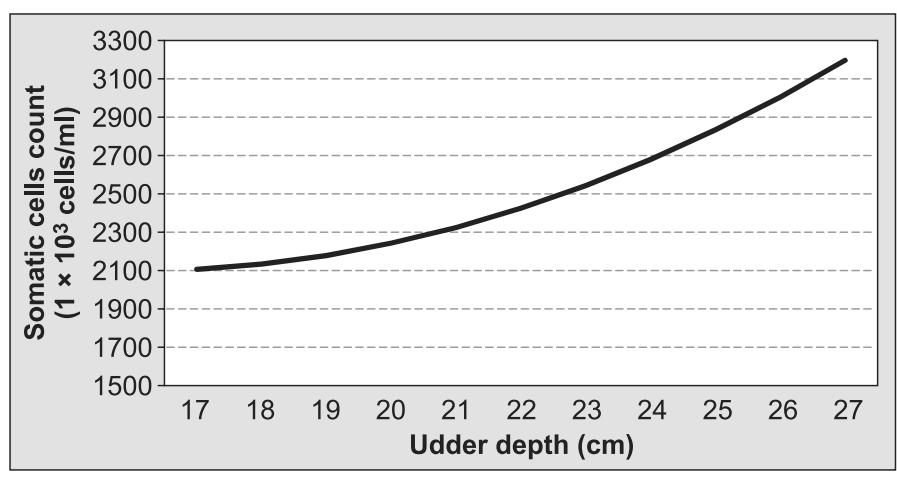

Fig. 3. The relationship between somatic cell count and udder depth

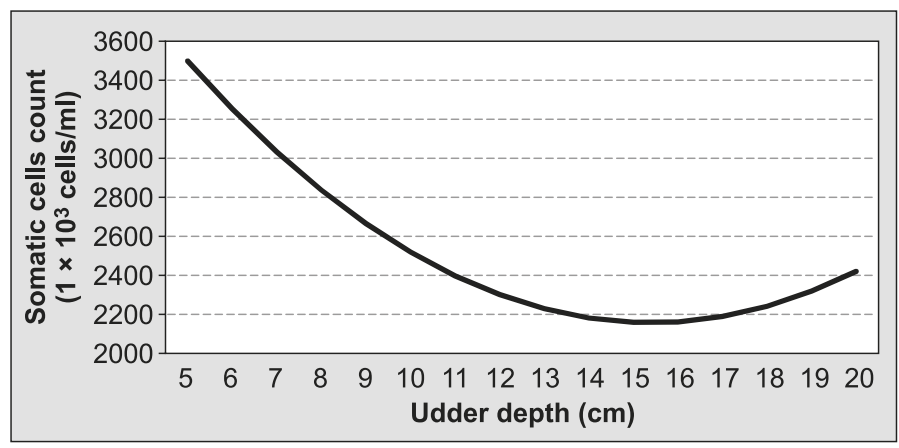

Fig. 4. The relationship between somatic cell count and udder width

the composition and technological properties of dairy products and thus contribute to the final quality of dairy products through endogenous enzymes (e.g. cathepsin $B$, cathepsin D, cathepsin $G$ and elastase). A higher amount of SCs accelerates the proteolysis process during cheese ripening and improves sensory characteristics of cheeses $(8,14,16,18)$. The ultrasonography of the udder is an exact method for the diagnosis of some physiological and pathological states of the mammary gland in ruminants (mastitis etc.). It makes it possible to avoid economic losses during milk production in the case of udder disease (1).

The linear description of the goat's udder was evaluated. This is a pilot study that will include other goat herds and breeds in future. Thanks to this methodical approach, it will be possible to describe the goat population in the Czech Republic and to start selection against udder shapes unsuitable for machine milking. 
The results demonstrate that the traits of the udder shape influence the somatic cell count, and so they can be regarded as functional traits indicating animal health and herd profitability.

\section{References}

1. Adam Z. E. A. S., Ragab G. A. N., Awaad A. S., Tawfiek M. G., Maksoud M. K. $M$. A.: Gross anatomy and ultrasonography of the udder in goat. J. Morphol. Sci. 2017, 34, 3, 137-142.

2. Boutinaud M., Jammes H.: Potential uses of milk epithelial cells: a review. Reprod. Nutr. Dev. 2002, 42, 133-147.

3. Contreras A., Sierra D., Sanchez A., Corrales J., Marco J., Paape M., Gonzalo C.: Mastitis in small ruminants. Small Rumin. Res. 2007, 68, 145-153.

4. Council Directive 92/46/EHS of the $16^{\text {th }}$ June 1992 laying down the health rules for the production of raw milk, heat-treated milk and milk-based products.

5. Dudko P., Junkuszew A., Bojar W., Milerski M., Szczepaniak K., Le Scouarnec J., Schmidová J., Tomczuk K., Grzybek M.: Effect of dietary supplementation with preparation comprising the blend of essential oil from Origanum vulgare (Lamiaceae) and Citrus spp. (Citraceae) on coccidia invasion and lamb growth. Ital. J. Anim. Sci. 2018, 17, 57-65.

6.Junkuszew A., Dudko P., Bojar W., Olech M., Osiński Z., Gruszecki T. M., Greguła Kania M., KuźmakJ., Czerski G.: Risk factors associated with small ruminant lentivirus infection in eastern Poland sheep flocks. Prev. Vet. Med. 2016, 127, 44-49.

7. JunkuszewA., Milerski M., Bojar W., SzczepaniakK., Le Scouarnec J., TomczukK., Dudko P., Studzińska M. B., Demkowska-Kutrzepa M., Bracik K.: Effect of various antiparasitic treatments on lamb growth and mortality. Small Rumin. Res. 2015, 123, 305-312.

8. Li N., Richoux R., Boutinaud M., Martin P., Gagnaire V.: Role of somatic cells on dairy processes and products: a review. Dairy Sci. Technol. 2014, 94 , $517-538$.
9. Lipecka C., Junkuszew A., Kuźmak J., Gruszecki T. M., Olech M.: Mortality of ewes and their progeny in a flock infected with maedi-visna virus. Bull. Vet. Inst. Pulawy 2011, 55, 361-365.

10. Maréchal C. Le, Thiéry R., Vautor E., Le Loir Y.: Mastitis impact on technological properties of milk and quality of milk products: a review. Dairy Sci. Technol. 2011, 91, 247-282.

11. Milerski M., Schmidová J.: Metodika lineárního popisu vemen u ovcí 2016 , Certifikovaná Metodika, Výzkumný ústav živočišné výroby, V.V.I., Praha Uhříněves, 16 Str., ISBN: 8074031489, 9788074031489.

12. Olechnowicz J., Jaśkowski J. M.: Somatic cells count in cow's bulk tank milk J. Vet. Med. Sci. 2012, 74, 681-686.

13. Olechnowicz J., Jaśkowski J. M.: Somatic cells in goat milk: Med. Weter 2004, 60, 12, 1263-1266.

14. Raynal-Ljutovac K., Pirisi A., De Cremoux R., Gonzalo C.: Somatic cells of goat and sheep milk: analytical, sanitary, productive and technological aspects. Small Rumin. Res. 2007, 68, 126-144.

15. Rupp R., Boichard D., Bertrand C., Bazin S.: Overview of milk somatic cell counts in the French dairy cattle breeds. Prod. Anim. 2000, 13, 257-267.

16. Sánchez-Macias D., Morales-delaNuez A., Torres A., Hernández-Castellano L. E., Jiménez-Flores R., Castro N., Argüello A.: Effects of addition of somatic cells to caprine milk on cheese quality. Intern. Dairy J. 2013, 29, 2, 61-67.

17. Sharma N., Singh N. K., Bhadwal M. S.: Relationship of somatic cell count and mastitis: a review. Asian Austral. J. Anim. 2011, 24, 429-438.

18. Souza F. N., Blagitz M. G., Penna C. A. M., la Libera A. M. M. P., Heinemann M. B., Cerqueira M. M. O. P.: Somatic cell count in small ruminants. Small Rumin. Res. 2012, 107, 65-75.

19. Tomczuk K., Grzybek M., Szczepaniak K., Studzińska M., DemkowskaKutrzepa M., Roczeń-Karczmarz M., Abdulhammza Abbass Z., Kostro K., Junkuszew A.: Factors affecting prevalence and abundance of A. perfoliata infections in horses from south-eastern Poland. Vet. Parasitol. 2017, 246, 19-24.

Corresponding author: Ing. Klára Novotná, Czech University of Life Sciences in Prague, Kamýcká 129, 165 21, Prague 6 - Suchdol, Czech Republic; e-mail: michnovak@af.czu.cz 